\title{
Diversification, Investment Opportunity Set, Envinronmental Dynamics and Firm Value (Empirical Study of Manufacturing Sectors in Indonesia Stock Exchange)
}

\author{
Yuliani $^{1}$, Djumilah Zain ${ }^{2}$, Made Sudarma ${ }^{3}$, Solimun ${ }^{4}$ \\ ${ }^{\prime}$ (Economics Faculty, University of Sriwijaya, Indonesia) \\ ${ }^{2,3,4}$ (Economics and Business Faculty, University of Brawijaya, Indonesia)
}

\begin{abstract}
The purpose of this research are: 1) to describe and analyzing the diversification effect on firm value, 2) to describe and analyzing the role of Investment Opportunity Set (IOS) diversification effect mediation on firm value, and 3) to describe and analyzing the role of environment dynamics as a IOS moderating effect on company value. The research was conducted on the manufacturing sectors in Indonesia Stock Exhange. Observation period are 2006-2010. Based on defined population criteria the sampling method is saturated sample or census. The samples analyzed were 18 companies. Analysis data method is Structural Equation Modeling (SEM) variance-based namely SmartPLS. The result shows that: 1) The diversification effect on firm value is significant and positive, 2) IOS mediation variable significantly and positively affect firm value, and 3) IOS*environmental dynamics interaction variable does not affect significantly on firm value.
\end{abstract}

Keywords: Diversification, Investment Opportunity Set, Environmental Dynamics, Firm Value.

\section{INTRODUCTION}

Revolution and globalization lead companies to choose diversification, when faced with a very tight competition and the market grow rapidly. Montgomery (1994) suggest that there are three motives perspectives to diversify, namely Market Power View-MPW, Resources-Based View RBV, and Agency View. David (2003: 167-170) states that development of new business is different from the existing business and involving a number of investment diversification. When a company chooses to diversify operations from one to several industries, it mean the diversification strategy done at the enterprise level (Hitt et al., 2011: 158-159).

Ansoff (1965) states that diversification is the evolution of business growth. Rumelt (1974), Hoskisson \& Hitt (1990) states that diversification is a corporate level strategy. Unlike Tecee et al. (1997), Matsusaka (2001) and Barney (2002) states that diversification can be used as a source of sustainable competitive advantage. Clarkson et al. (1983), Nayyar (1993) suggested diversification is the source of value creation. Rumelt (1974) states there is a correlation between the diversification of corporate diversification and company performance, including Strategic Management and Financial Management.

Studies of diversification and its impact on the firm value is still debating, whether diversification can bring benefit or even a negative impact on firm value. The studies suggesting that diversification increases the firm value are: 1) On average, higher profitability relate to diversification companies than non-diversified company (Amit \& Livnat, 1988; Rumelt, 1982; Aisjah, 2009). 2) Diversification does not reduce the company's enterprise value (Gomes \& Livdan, 2004). 3) Diversification associated with technology diversity (Miller, 2004, 2006). 4) International Diversification did not lower the firm value (Santos et al., 2008). 5) Diversification has positive influence on the performance of companies in Indonesia (Chakrabarti et al., 2007).

However, research on the effect of diversification on firm value find the opposite result. First, the value of diversified companies are smaller than companies that operate in a single segment. Value loss ranged from $13 \%-15 \%$. Difference in value will be reduced if the company made related diversification (Berger \& Ofek, 1995). Second, there is a negative relationship between Tobin's q ratio on diversification (Lang and Stulz, 1994; Campa \& Kedia, 2002; Fukui and Ushijima, 2007). Third, no significant effect on diversification Excess Value and profitability (Harto, 2005; Kusmawati, 2005, Satoto, 2009, Yuliani, 2011). Four, diversified companies have asymmetric information problems than the company's focus (Clarke et al., 2004).

Various previous studies on the effects of diversification on companies value is still not consistent. This creates a gap, with variable operationalize Investment Opportunity Set (IOS) as a mediation between the effect of diversification on companies value. Reason to include variables when a company is to diversify, namely there are a number of investments that will be involved. Diversification opportunities for the company will create investment opportunities that should be implemented. Investment opportunities in financial management in the context of investment decisions entry. Research Fama and French (1997) has shown that only determinant of the firm value is an investment decision. 
Myers (1977) firstly introduced the Investment Opportunity Set (IOS) in relation to achieving the company's goals. Gaver and Gaver (1995) stated that IOS provides guidance a broader, enterprise value as the primary goal depends on corporate spending in the future, which is now the investment options that are expected to yield a greater return. IOS is a combination of assets in place and future investment choices with a Net Present Value (NPV) positive (Myers, 1977; Kallapur \& Trombley, 1999). Adam and Goyal (2008) emphasizes that IOS plays an important role in corporate finance related to the achievement of corporate goals. Smith \& Watts (1992) explains that IOS is a component of the company's value results from the choices to make future investments.

Empirical studies the IOS influence on companies value outcome remains consistent. On the one hand, IOS influence on companies value (Fama, 1997; MacKay, 2003; Hasnawati, 2005a, 2005b; Hossain et al., 2005; Yoon and Starks, 1995; Nopratiwi, 2004; Hidayat, 2010; Akhtaruddin \& Hossain, , 2008; Efni, 2011). But on the other hand, Kallapur \& Trombley (1999); Suharli (1997) and Bernadi (2008) found that IOS has no effect on companies value. IOS effect on companies value, which means that investment opportunities that exist, if the company is able to choose from different investment companies will acquire surplus for a number of investments made. Surplus proceeds will be contributed to the cash inflow, and then accumulated in improving profitability. Conversely, if the IOS does not affect the company then the company has a deficit in the number of investments made, which will reduce the equity and will ultimately lower the firm value.

This study develops a diversified variable relationships, IOS and the firm value, as well as fill the research gap of Lang and Stulz (1994) and Fukui and Ushijima (2007). Research of Lang and Stulz (1994) in the United States and Fukui and Ushijima (2007) in Japan showed inconsistent results. In fact, the two researchers using the same performance indicators Tobin's $\mathrm{Q}$. This study fills the gap by offering a single solution, which operate as a mediating influence between IOS diversification on companies value. IOS mediating variable will make an increasingly broad diversification, it will lead to a variety of investment opportunities. Existing investment opportunities encourage companies to choose investments with a high rate of return. Therefore, the company earned surplus, which in turn increases the firm value.

Every investment decisions need to concern the environment condition, both internal and external environments. Internal environmental concern with overall conditions derived from the company, including resources, capabilities and firm core competencies. The external environment is the general environment, industry and competitors (Hitt et al., 2011:16). Wheelen and Hunger (2000:10) describes industry environment is part of external business environment that may affect the performance achievement, in addition to macro environment. Macro environment consists of economic, ecological, legal, political, social, cultural and technological. The internal environment consists of organizational structure, organizational culture and resources.

The results also indicate that environment can affect corporate performance (Keats \& Hitt, 1988). Even Mc Arthur \& Nystrom (1991) focuses on relationship the three-dimensional environment namely dynamic, complex environment and liberal environment. Dynamic environments portrayed in some form. Mintzberg (1979) reflects the instability or turbulence or volatility that happens all the time, due to interconnection or relationship between the organization or company. Hambrick (1983) operationalize dynamic environment as the latest product innovation that shows the main influences on performance measurement.

Environment is an important variable to examine the relationship between investment performance (Hitt et al., 1990). However, the concept must be seen in context of evaluating the investment relationship performance. This is because environmental factors have contingency characteristics that always changes. Some researchers such as Luthans \& Stewart (1977); Mealiea \& Lee (1979) puts environmental factors as control variables in explaining performance. But Hosskison \& Hitt (1990) suggest that environment become a moderating variable source of firm value creation.

Some researchers classify the environment in different ways. Balakrishnan \& Wernerfelt (1986) classifies the environment with environment uncertainty, as measured by two indicators: volatility and diversity. Both of these indicators have strong influence on organizational decision processes. Keats \& Hitt (1988), Dess $\&$ Beard (1984) classifies the environment as three indicators, namely munificence, instability (Dynamism) and complexity. This study uses three indicators to make environmental characteristics namely munificence, volatility and complexity, which is a distinct characteristic of firm value creation source.

Empirical proof of previous studies revealed inconsistent results. There are several possible explanations of the differences in previous research studies results. First, the concept of diversification measurement on firm value is an indication of company to diversify, be interpreted as reflective indicators, such as Lang and Stulz (1994), Fukui and Ushijima (2007), Kusmawati (2005), Sulastri (2006). Second, research the diversification effect on firm value in the previous studies have not been linked with investment opportunities, particularly the observation object of manufacturing sector in Indonesia. In fact, diversification policy become one of investment decisions for fund managers, that in turn will lead to firm value. Third, environment dynamics has not been discussed in previous studies, to examine the relationship IOS on firm value. 
This study develops a diversified variable relationships, IOS , environmental dynamics and firm value as well as filling the research gap from Lang and Stulz (1994) and Fukui and Ushijima (2007). Research gap of Lang \& Stulz (1994) and Fukui and Ushijima (2007) was the inconsistent results, but the company's performance indicators using Tobin's Q. Thus, this study fills the gap by offering a single solution, which operate as a mediating influence between IOS diversification on firm value. By entering the mediating variable IO, it is hoped that diversification will lead to an increasingly broad range of investment opportunities. The existing investment opportunities prompted the company to choose investments with a high rate of return, so the company earned surplus, which in turn increases the firm value. There is a growing investment opportunities that encourage companies to observe and analyze the environmental factors. This study focused on an industrial environment as a part of external environment. Many investment opportunities should be supported by environment dynamics, in a positive sense, such as the availability of resources are not unlimited, able to cope competition expected to contribute the increased firm value.

This study is organized into several sections. Section 2 discusses the fundamental theories of diversification, IOS and environmental dynamics. Section 3 discusses the hypotheses development. Section 4 presents the research methods. Section 5 convey research findings. Section 6 discussion research. Finally, section 7 conveyed conclusions with some implications and recommendations.

\section{Market Based View (contingency theory)}

\section{Fundamental Theories Of Diversification}

The first argument refers to Porter opinion (1980:3-5). Basic formulation of competitive strategy is to connect the company with its environment. The higher competitive with competitive approach, companies must be able to distinguish his position with competitors in an industry environment, to create competitive advantage. Porter Said the corporate environment was an industry where the company compete. The industrial structure has a strong influence in determining the competition rules and there is a strategy game potentially available to company. Competition in an industry is rooted in its underlying economic structure and goes beyond existing competitors behavior. The competition in an industry depends on five basic competitive forces.

Barney (2002) explains that diversification is one strategies to overcome the competition. By diversifying, companies can build market power. Clarkson \& Miller (1983), Scherer (1980) in Sulastri (2004) states that market power can lead to collusion (collusion Theory). Companies that have high market power would easily exercise control over the market price to make a profit above average. Palich et al. (2000) found that firms with market power would be easier to practice discounts, cross subsidies and reciprocal purchase and sale as a tool to prevent potential competitors enter the industry.

Market-based view approach explains that company diversify with motivation to overcome the competition complexity, to build financial strength and cost efficiency. Market-based view approach is part of contingency theory (Ginsberg \& Ventkatraman (1985), Luthans and Stewart (1997), Fisher (1998), Dickinson and Ramaseshan (2004), Ray (2004). Mealia \& Lee (1979) stated the organization success depends on integration of macro and micro factors as contingency variables. Based on MBV context, diversification undertaken to overcome the competition, a way to build market power. The ultimate goal of this approach is cost efficiency and building financial strength.

\section{Resource Based View (RBV)}

RBV approach (Teece, 1997; Barney 1991) uses assumption that company undertake managerial efforts to steer the SCA. Penrose (1959) concert to that company as a set combination of resources, so there is the growth of the firm theory. This theory explains that company's growth is limited by opportunities that exist as a function of a set of the company's earning power source. Penrose's theory gave birth to RBV, which later became one of the most dominant approaches to the analysis of SCA.

RBV basic reason was the guide, type, amount and nature of enterprise resources should be considered first in selecting, establishing strategies that can lead to sustainable competitive advantage. David (2003:180) uses RBV approach to gain a competitive advantage, believe that internal resources is more important for the company rather than external factors, in order to achieve and sustain competitive advantage.

Prahalad \& Hamel (1990) suggests the emergence of large firms because the success in building distinctive capabilitas as a source of SCA. Barney (1991) also argues that diversification can create economies scope by sharing activities and core competences transfer as a source of SCA. The essence of RBV is an action strategy to position relationship between the business unit as a foundation for the organization multibisnis, and emphasizes the company's ability to exploit the potential synergies between resources, to produce higher performance. Hitt et al. (1997:18) describes resources as inputs to production process, such capital goods, workers ability, patents, finances and talented managers. In general, resources are classified into three categories: physical, human and organization resources. 
Key RBV models based on three resources as main foundation in discovering and developing core competencies. Core competencies are considered as a capability or expertise within company business. Peace \& Robinson (2011: 215) stated resource is separated into three, called the core resources, as the basis for specific competencies. They are tangible assets, such as buildings; intangible assets, such as leases, organization costs, licensing, patents, trademarks, franchises, goodwill, and organizational capability.

Potential economic diversification using the RBV focuses on resource allocation (sharing activities) and competence transfer. Exploitation of potential synergies expected from sharing activities through joint cost that will result in distinctive as a source of competitive cost. Exploitation of competence potential synergies expected from complementary assets, in turn generate a distinctive competitive advantage (Barney, 2002). In this case, the cost is distinctive advantage and SCA distinctive sources. Based on the company's resources as an input to production process that consists of physical resources, human resources and organization, it will determine what abilities owned by firm. Capabilities should be integrated as a single unit, allowing the company become better than its competitors. This potential is a source of SCA, so the company able to outperform its competitors, in figure above is linked to the profit achievement as one of business activity. Currently the company has resources and capabilities that can not be duplicated and can not be replaced, the company will choose and implement strategies to obtain above-average profits.

\section{Internal Transaction Cost}

In diversification context, internal cost efficiency is possible if the company develops diversification through vertical integration between complementary business. Development of vertical integration and complementary businesses be done to meet assumptions of Transaction Cost Economic-TCE. There is a relationship between the frequency the business unit intensity to cope uncertainty and a prioritized on specific business transactions.

Porter (1980: 263) explains that vertical integration is a combination of production processes, distribution, sale and / or other economic processes, which are different technologies within the boundaries of a single firm. This reflects that company's decision was to use internal transactions rather than market transactions in order to achieve economic goals. According to Porter, one benefits of vertical integration is company improve the company's ability to offer a value added differentiation and more under management control.

David (2003:161-162) also outlines that vertical integration allows a company to gain control over distributors, suppliers and competitors. Vertical integration strategy divided into three part namely : forward integration, backward integration, and horizontal integration. Something to distinguishes the three are seeking ownership or increased control over distributors or retailers (forward), firms suppliers (backward) and competitors (horizontal).

TCE view assumes that value creation can be obtained through the reduction of transaction cost inefficiencies (Foss, 2003). This theory preceded Coase in 1937, states the cost happened because the market mechanism would be smaller if the company able to coordinate the transaction. Williamson (1989) connects the market with the managerial hierarchy in company organization, to support interactions within company to provide lower incentives cost with greater ownership than the market, which includes ownership and contractual rights in a multi-business company. In Williamson view, the change from non-market to market based on two assumptions: individual rationality is limited (bounded Rationality) and opportunism nature of economic actors.

The focus of transaction cost theory lies in the argument that in order to keep the contract could go well then it need costs. Each contract basicly done in a limited rationality situation. Based on these properties, the information never occurs symmetrically (asymmetry information). In other words, the transaction costs would arise because the information is not available perfectly. Thus, firms exist because companies are more efficient than market. Efficiency occurs because internalization of transaction costs and market monitoring mechanism against opportunistic behavior and economic actors (Williamson, 1989).

\section{Agency Theory}

Agency theory (Jensen \& Meckling, 1976) explains that separation between the owner and manager of company will always followed by emergence of cost because the lack of interests alignment between owners and managers. These costs are called agency costs, include: expenditure to monitor the managers activities, expenditure to create an organizational structure to minimizes the unwanted managers actions, as well as the opportunity cost arising from the condition in which the manager can not make decisions immediately without shareholder approval. One important implication of the agency problem is related to the company's financial policy, especially against two choices whether using debt or equity to finance business activities.

Jensen (1986) explains that interest conflict between managers and shareholders occurs with assuming the owners (shareholders) and managers (agents) each want a high return on investment to projects but with different interests to risk (Jensen, 1986; Ammihud \& Lev, 1981; Lane et al., 1998). The difference is explained by the risk (Ammihud \& Lev (1981), that shareholders more interested in the systematic risk, while managers 
were more interested in the unsystematic risk. In particular, these conflicts occur in companies with substantial free cash flow, because the manager will choose to invest excess cash to optimize profit, compared with a cash payment to shareholders.

Based on description above, agency theory can explain why firms diversify, and also explains why diversification does not create value for company. The essence was diversification undertaken to gain efficiencies and to ensure benefits to all stakeholders that organization's activities are run in a professional manner and free from any interest conflict. Therefore the firm value should be increased. Rationality is a diversified company to address the agency conflicts within firm. Diversification can provide incentives for agents through investment and ownership. Therefore, the emphasis is not only based on performance evaluation of financial outcomes, but more emphasis on optimize behavior (Jensen \& Meckling, 1976; Jensen, 1986; Adams, 1994).

\section{Investment Opportunity Set (IOS )}

The IOS term was introduced by Myers (1977). It describes the extent or number of investment opportunities in relation to achieving the company's goals. The number of investment opportunities demanding the firm should be able to choose the appropriate investment type. Gaver \& Gaver (1995) stated that IOS provides broader guidance. Firm value as the primary goal depends on corporate spending in future, now is the investment options that are expected to result in a larger return. IOS is a combination of outstanding assets and investment options in the future, with a Net Present Value (NPV) positive (Myers, 1977; Kallapur \& Trombley, 1999).

Adam \& Goyal (2008) emphasizes that IOS plays an important role in finance company to achieve its goals. Smith \& Watts (1992) also explained that IOS is a component of the company's value resulted from the choices to make investments in future. Kallapur \& Trombley (2001) states that company IOS influence the way companies are rated by managers, owners, investors and creditors. While Kole \& Lehn (1991) explains that IOS value depends on expenditures that by future management and today investment options choice is expected to provide a return greater than cost of capital to make a profit. Even associated with the movement of stock prices, Koaesnter \& Liu (1998) stated that IOS becomes the dominant factor.

From the above definition, it can be interpreted that IOS contains two terms. First, the IOS is an investment decision by company to deliver positive growth, so the IOS be thought as growth prospects. Secondly, IOS is company ability to determine what investments types to be carried out. For companies that are not able to choose the investment right will have higher spending than the value of lost opportunity. Therefore, it can be concluded that IOS is a relationship between current spending and future value /return/prospects as a result of investment decisions to generate shareholder value.

IOS is often associated with the company's growth by Sharpie (1991); Saputro \& Hartono (2002), Voght (1997), Smith \& Watts (1992). IOS is interpreted differently by McDonald \& Siegel (1986); Pindyck (1993), states that IOS is an investment option that generates positive NPV while the growth is company ability to enhance shareholder value. Jensen (1986) explains that cash investment for acquisitions can increase company size without increase value. The company's ability to acquire other companies was not IOS components and does not produce value.

\section{Environmental Dynamics}

Companies can obtain the information needed to understand current conditions, and predict the future. Therefore, the integration between environment should be a concern. Environment are classified into internal and external. The external environment consists of two main components, namely general environment and the industry environment (David, 2003:39). General environment include an element in society that can influence an industry and the companies within it. These elements are grouped into the environment segments, consisting of demographic, economic, political/legal, physical, social, cultural, global and technology segments. The Company can not control these elements directly. Therefore, the strategic challenge is to understand each segment and the implications, so appropriate strategies can be formulated and implemented.

Industry environment is a factors set that influence a company, such as entry threat of new entrants, suppliers, buyers, substitute products and rivalry intensity between competitors. Overall, the interaction between these five factors determine the position in the industry in which firms can influence these factors properly, or to defend themselves from the influence the above factors. The bigger the capacity company to influence industry, the greater the tendency to make a profit above average. Competitor analysis is a prediction of rare dynamics, responses and intentions of competitors. Company overall performance will increase if company integrates the general environment analysis, industry environment and competitors. The focus of this research is industrial environment. The challenge for companies is to determine the position in industry where the company located. Position in industry means that companies will see the market structure. 
Industry environment analysis is much more important and more decisive than competition rules of general environmental analysis. It can be illustrated that if environment changes, e.g, the changes in segments of demographic, economic, political/legal, physical, social, cultural, global and technology, then it is subject to influence because it changes all companies that exist in the industry. Therefore, if there is a change in the public level, the key success lies in the different capabilities of each company to address the changes implications.

\section{Hypothesis Development}

The study's findings are inconsistent regarding the relationship of diversification on firm value. Hitt \& Hokisson (1990) suggests, diversification relation with the performance of non-linear form, i.e the higher the degree of diversification the lower performance. Palich et al. (2000) suggests, diversification and performance relationship can be linear and non-linear. The linear relationship between diversification and performance has been described by MBV approach. Diversification can enhance market power, facilitate the implementation of pricing practices, and cross-subsidies between businesses. Therefore, it exploits the synergy of economic diversification. In the non-linear forms, business diversification can lead to control difficulties. Therefore, high diversification will lead to greater marginal cost, so the high diversification causes a decrease in the firm value. Montgomery (1994) explains that reason diversification company is looking to diversify the market. That is, the market share control will greater. Another reason is to optimize existing resources. Montgomery \& Wernerfelt (1988) stated that diversified company, it will first try to use excess assets to the nearest market to enter. If there is still excess capacity, the company will enter the market more deeply. But if the assets used in the market too much with the current market, companies will lose their competitive edge and low profit. This indicates that relationship between diversification and marginal profit is diminishing function. Several studies have also concluded that diversification is more profitable for companies in emerging economies (Khanna \& Palepu, 1999). The reason is that in countries with developing economies, capital market intermediaries often run inefficiently or even absent. Based on explanation above, the hypotheses formulation of diversification effect on firm value is:

\section{Hypothesis 1: The more extensive secondary sector company to diversify, the higher firm value}

Investment Opportunity Set as an investment option depends on the value of future discretionary expenditure growth chosen by manager (Kole, 1991). Each choice is influenced by the growth of competitive advantage in business. Diversification can be done because the company has investment opportunities set. Investment opportunities means the company will have a good value, reflected in the stock price as well as for other indicators. IOS plays an important role in corporate finance related to the achievement of corporate goals. Singh et al, (2003) and MacKay (2003) conduct empirical research on the effects of diversification to IOS. The results showed that company was not consistent because the opportunity to diversify their investments is differ. Investment Opportunity Set selected based on resource considerations, strategic assets and market share. When companies implement diversification, they will contribute to the increased firm value. IOS acts strengthen the company to diversify. Therefore the presented hypothesis as follows:

\section{Hypothesis 2: IOS mediate the diversification effect to firm value.}

Rapid changing environmental factors are automatically requires every business people to always pay attention and to response. Therefore, it required series of activities which include the business environment, both internally and externally. This study focuses on industry, as it becomes more important than observing the general environment. Environmental dynamism, industry (the dynamics of customer, supplier, substitutes, new entrants and competition) and business will determine competition rule. Environmental dynamics represent the change in conditions that can not be predicted. Environmental dynamism has rapid and discontinuous environment characteristics, for example in terms of demand, competitors, technology and regulations (information being inaccurate, outdated and even not available). Business environment dynamics will be an important variable to examine the relationship between investment and performance. Some researchers suggest that environmental factors have a contingency characteristics that always changes (Mealiea \& Lee, 1979; Ginsberg \& Ventkatraman, 1985). Tan (2002) suggests that environmental factors will be considered in company decision strategy, in this case investment, because of its potential to create value and can also lower the firm value. therefore, the company dynamics existence need to consider.

The findings of investment decisions complexity also showed different results among some researchers. Wilkmund \& Shepherd (2003) suggests that environmental heterogeneity does not significantly influence the performance, in line with Goezen \& Beamis (2003) which states that country environment diversity negatively affect economic performance. Dynamic industry environment are supporting capacity, volatility and complexity. The bigger company's dynamic industrial environment, the greater opportunity to choose an investment, which is a way to enhance shareholder value. The formulation of this hypothesis are: 


\section{Hypothesis 3: The environment dynamics as a moderating influence of IOS on firm value.}

\section{Research Design}

\section{Research Methods}

The research design is a quantitative study with paradigm positivism by empirical research on the go public secondary sector companies in IDX. While this type of research is explanatory (explanatory research), the aim is to find an explanation of the relationship (causality) between variables through hypothesis testing.

\section{Population and Sampling}

The study population was all companies included in the secondary sector in IDX. This includes basic industry and chemicals ( 6 sub-sectors), miscellaneous industry ( 3 sub-sector), consumer goods industry ( 5 subsectors) during the observation period 2006-2010. Object of observation in the study is the annual report 2010 amounted to 136 issuers. Population criteria include: 1) The company publishes audited financial statements 2006-2010. 2) The company did not incur losses. 3) The company has positive retained earnings. 4) The Company has a positive equity balance, and 5) The company has more than one type of business. Based on these criteria, the amount eligible is 18 companies. This study used a sample saturated (census). The unit of analysis is the pooling of data with lag time during the observation period (t) by the number of observations 72 cases. Companies that entered the samples shown in Table 1:

Table 1 Sample Research

\begin{tabular}{l|lll}
\hline No & Emiten & Code & Sub-sector \\
\hline 01 & Indocement Tunggal P Tbk & INTP & Cement \\
02 & Ekadharma International Tbk & EKAD & Chemicals \\
03 & Charoen Pokphand Indonesia Tbk & CPIN & Animal Feed \\
04 & Astra Otoparts & AUTO & Automotive and Comp. \\
05 & Indo Kordsa Tbk & BRAM & Automotive and Comp. \\
06 & Indospring Tbk & INDS & Automotive and Comp. \\
07 & Selamat Sempurna Tbk & SMSM & Automotive and Comp. \\
08 & Sumi Indo Kabel Tbk & IKBI & Cables \\
09 & Indofood Sukses Makmur Tbk & INDF & Food and Beverages \\
10 & Mayora Indah Tbk & MYOR & Food and Beverages \\
11 & Siantar Top Tbk & STTP & Food and Beverages \\
12 & Ultra Jaya Milk Tbk & ULTJ & Food and Baverages \\
13 & Darya-Varia Laboratoria Tbk & DVLA & Pharmaceuticals \\
14 & Merck Tbk & MERK & Pharmaceuticals \\
15 & Pyridam Farma Tbk & PYFA & Pharmaceuticals \\
16 & Mustika Ratu Tbk & MRAT & Cosmetics and Household \\
17 & Unilever Indonesia Tbk & UNVR & Cosmetics and Household \\
18 & Kedawung Setia Industrial Tbk & KDSI & Houseware \\
\hline
\end{tabular}

\section{Measures}

Variables type of this study consists of exogeneous variables: diversification, endogenous variable: IOS and firm value. IOS is also become a mediating variable. Moderating variable: environmental dynamics. So that study focused and suitable with the goal, the research variables are defined as follows:

Table 2 Operational Definition of Research Variables

\begin{tabular}{|c|c|c|}
\hline Variables & Indicators & Measurement \\
\hline \multirow{4}{*}{$\begin{array}{l}\text { Diversification }\left(\mathbf{X}_{1}\right) \\
\text { Is the breadth of the company's } \\
\text { efforts to diversify into different } \\
\text { businesses, types of businesses } \\
\text { that can be operated in different } \\
\text { industries. This variable refers to } \\
\text { Montgomery (1994) perspective }\end{array}$} & Market Share t-1 $_{1}$ & Sales/sales industry \\
\hline & Free Cash Flow ${ }_{t-1}$ & $\begin{array}{l}\text { Retairned } \\
\text { earning }+ \text { depreciation+amortizat } \\
\text { ion }\end{array}$ \\
\hline & Size $_{t-1}$ & $\operatorname{Ln} T A$ \\
\hline & Compensation $_{t-1}$ & $\begin{array}{l}\text { Renumeration paid to the boards } \\
\text { of commissioners and directors }\end{array}$ \\
\hline \multirow{3}{*}{$\begin{array}{l}\text { Environment Dynamics }\left(\mathbf{X}_{2}\right) \\
\text { Are the factors and turbulent } \\
\text { industry environment conditions }\end{array}$} & Munificence $_{t-1}$ & $\Delta$ sales/industry sales \\
\hline & Volatility $_{t-1}$ & Variance $\Delta$ industry sales \\
\hline & Complexity $_{t-1}$ & Total biggest sales /industry sales \\
\hline $\operatorname{IOS}\left(\mathrm{y}_{1}\right)$ & MBA Ratio $_{t-1}$ & $(T A-T E)+(O S x S P) / B V A$ \\
\hline
\end{tabular}




\begin{tabular}{|c|c|c|}
\hline \multirow{3}{*}{$\begin{array}{l}\text { The company's ability to } \\
\text { determine what investments types } \\
\text { to be implemented }\end{array}$} & 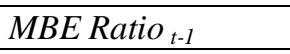 & \multirow{3}{*}{$\begin{array}{l}(O S x S P) / T E \\
E P S / S P \\
F A / B V A\end{array}$} \\
\hline & EP Ratio $_{t-1}$ & \\
\hline & CEFA/BVA Ratio $_{t-1}$ & \\
\hline Firm Value $\left(\mathbf{y}_{2}\right)$ & Tobin's $Q_{t}$ & $(O S x S P)+(D+I)-C A / T A$ \\
\hline $\begin{array}{l}\text { Firm value is a success measure } \\
\text { of past operations management }\end{array}$ & $\mathrm{ROIC}_{t}$ & EBIT/EQUITY \\
\hline
\end{tabular}

and future prospects

Description: TA = Total Assets; TE = Total Equity; OS = Outstanding Share; $\mathrm{SP}=$ Share Price; BVA $=$ Book Value of Assets; EPS = Earnings Per Share; FA = Fixed Assets; D = Total Debt; I = Inventory; CA = Current Assets; EBIT = Earnings Before Interest and Tax.

\section{Assumptions Linearity Test}

\section{FINDINGS}

Assumptions Linearity Test used to determine whether the model obtained has been appropriate in describing the relationship between variables that are categorized into good model or termed as model fit. Basic testing used is a method of curve estimation by SPSS software. Whether there is linear relationship between variables is decided using $\mathrm{p}=5 \%$. The result of linearity assumption for any relationship between variables are presented in Table 3 below:

Table 3 Results Linearity Testing Assumptions

\begin{tabular}{llrc}
\hline \multicolumn{1}{c}{ Exogeneous Variable } & Endogenous Variable & Significance & Decision \\
\hline Diversification & Firm Value & 0,000 & Linear \\
Diversification & IOS & 0,000 & Linear \\
IOS & Firm Value & 0,000 & Linear \\
Environmental Dynamic & Firm Value & 0,036 & Linear \\
\hline
\end{tabular}

Source: Adapted from Secondary Data

Table 3 above show that all relationships between variables in structural model is linear based on significance level less than 5 percent $(\mathrm{p}<0.05)$. Thus, the assumption of linearity in the structural model has been fulfilled.

\section{Measurement Model Test}

Model measurements examination performed by model outer interpretation or outer weight loading, formative and reflective indicators, to measure strong or dominant indicators or in this study use fit. This study used four latent variables with 10 indicators. Latent variable of diversification is formative whereas IOS and firm value variable is an indicator that is reflective. Examination for formative indicators are based on weight and then compared with the outer $\mathrm{p}$ value at 5\% alpha. The indicator is based on a reflective outer loading and compared with the $\mathrm{p}$ value at $5 \%$ alpha. This examination is conducted to identify what indicators most important and dominant or fit in shaping or reflecting each latent variable.

Table 4 Testing Results Indicators Research Variables

\begin{tabular}{llllll}
\hline Variables & Indicators & $\begin{array}{l}\text { Outer } \\
\text { Weight }\end{array}$ & $\begin{array}{l}\text { Outer } \\
\text { Loading }\end{array}$ & T-Statistik & P-Value \\
\hline Diversification & MS $_{\mathrm{t}-1}$ & 1,118 & & 11,590 & 0,000 \\
& FCF $_{\mathrm{t}-1}$ & $-0,158$ & & 1,102 & 0,238 \\
& Size $_{\mathrm{t}-1}$ & 0,018 & & 0,190 & 0,839 \\
& Compen $_{\mathrm{t}-1}$ & 0,111 & & 2,970 & 0,007 \\
\hline Environmental Dynamics & Munificence $_{\mathrm{t}-1}$ & & 0,670 & 10,695 & 0,000 \\
& Volatility $_{\mathrm{t}-1}$ & & 0,551 & 7,997 & 0,000 \\
& Complexity $_{\mathrm{t}-1}$ & & 0,808 & 19,647 & 0,000 \\
\hline IOS & MBAR $_{\mathrm{t}-1}$ & & 0,967 & 256,899 & 0,000 \\
& MBER $_{\mathrm{t}-1}$ & & 0,973 & 198,656 & 0,000 \\
& EPR $_{\mathrm{t}-1}$ & & $-0,465$ & 3,906 & 0,000 \\
& CEFA/BVA $_{\mathrm{t}-1}$ & & 0,123 & 1,197 & 0,230 \\
\hline Firm Value & Tobin's $_{\mathrm{t}}$ & & 0,819 & 34,066 & 0,000 \\
& ROIC $_{\mathrm{t}}$ & & 0,765 & 26,541 & 0,000 \\
\hline
\end{tabular}

Source: Adapted from Secondary Data 
Table 4 shows the indicators that make up the dominant indicator of diversification are market share and compensation. Two indicator variables forming diversification is fit. Indicators of free cash flow and size does not fit. For further processing, the unfit indicators are not eliminated in diversification variable measurement. The characteristics of formative indicators can be assumed as inter-correlated indicators. Eliminating the indicator will change the meaning of the latent variables (Solimun, 2010: 94). Eliminating the indicator would eliminate the unique part of the diversification latent variables and change the meaning of latent variables. Therefore, free cash flow and fixed compensation put to hypothesis analysis process.

Outer loading values in Table 4 shows that there is one negative indicator and CEFA/BVA has a $\mathrm{p}$ value greater than $5 \%$. Both of these indicators dropped from hypothesis analysis. Basic indicators in determining the dropping, according to the characteristics of reflective indicators, the indicators are assumed to be inter-correlated, removing one indicator of measurement model would not change the meaning and significance of latent variables (Solimun, 2010: 39). Dominant indicators that become reflection of IOS latent variable are MBER and MBAR. All indicator of firm value are fit. Therefore, all the indicators included in hypothesis analysis process. Dominant indicator according to the value of the outer loading is Tobin's Q.

\section{Model Goodness of Fit Test}

The model in this study is declared fit if supported by empirical data. Examination Goodness of Fit structural model, analyzed by predictive value-relevance (Q2), calculated based on the value of R2, indicating each endogeneous variable and Q2 value are 0.648 or $64.8 \%$ (Table 5). That is, the model used in this study can explain the firm value amounted to $64.8 \%$, while the remaining $35.2 \%$ is explained by other variables not included in the research model.

Table 5. R Square Value of Endogeneous Variable

\begin{tabular}{cc}
\hline Endogeneous Variable & R Square \\
\hline IOS & 0,422 \\
Firm Value & 0,391 \\
\hline Predictive-relevance $\left(Q^{2}\right)$ & 0,648 \\
\hline
\end{tabular}

Source: Adapted from Secondary Data

\section{Hypothesis Testing Results (H1)}

Table 6. Hypothesis Testing Results

\begin{tabular}{llrrrl}
\hline $\begin{array}{l}\text { Exogeneous } \\
\text { Variable }\end{array}$ & $\begin{array}{l}\text { Endogeneous } \\
\text { Variable }\end{array}$ & \multicolumn{1}{l}{$\begin{array}{l}\text { Path } \\
\text { Coefficient }\end{array}$} & t-statistic & p-value & Explanation \\
\hline Diversification & Firm Value & 0,316 & 2,428 & 0,018 & Significant \\
Diversification & IOS & 0,650 & 16,099 & 0,000 & Significant \\
IOS & Firm Value & 0,267 & 4,221 & 0,000 & Significant \\
ED & Firm Value & 0,249 & 4,108 & 0,000 & Significant \\
IOS*ED & Firm Value & $-0,217$ & 1,092 & 0,279 & Nonsignificant \\
\hline
\end{tabular}

Source: Adapted from secondary data

Description: ED= Environmental Dynamics; Significant at $\alpha=5 \%$

Table 6 shows that each of the independent variables have a positive and significant effect on the dependent variable. The direct effect of diversification on firm value is significant and positive, the value of $s$ path coefficient is 0.316 and p-value less than 0.05 . The direct effect of diversification on IOS is significant and positive. Big path coefficient is 0.650 and p-value less than 0.05 . The direct effect of IOS on firm value is 0.267 , p-value less than 0.05 . Therefore, the effect is significant and positive. The direct effect of environmental dynamism on firm value is significant and positive path coefficient 0.249 and p-value less than 0.05 . Interaction between IOS*ED have affect to firm value is not significant with path coefficient -0.217 and p-value greater than 0.05 . Table 5 shows the results of a positive and significant effect of diversification on firm value. The first hypothesis which states the more extensive secondary sector companies to diversify, the higher company's value is received (H1 Accepted).

\section{Hypothesis Testing Results (H2)}

Testing mediating variables influence also called indirect effect testing, aims to determine the position of mediating variable (IOS) in this study. The process of examination the IOS variable in determining the type of mediation, whether partial or complete mediation steps are as follows:

Step 1: Calculate the path coefficients. The way is to enter the IOS variable in the model and the empirical test results, as shown in Table 7: 
Table 7. Mediation Test Results Analysis with Variable IOS

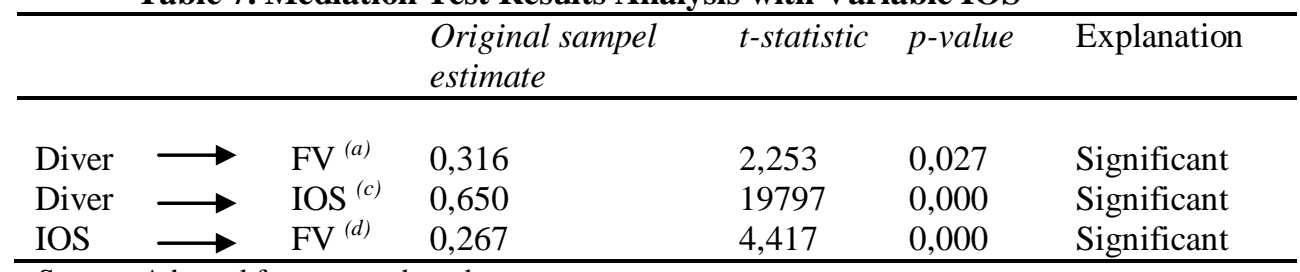

Source: Adapted from secondary data

Step 2: Calculate the path coefficient without entering the IOS variable in empirical models. The test results are shown in Table 8 follows:

Table 8. Result Analysis of Variable Test Mediation Without IOS

\begin{tabular}{lllll}
\hline & $\begin{array}{l}\text { Original sample-el } \\
\text { estimate }\end{array}$ & t-statistic & p-value & Explanation \\
\hline Diver $\longrightarrow \mathrm{FV}^{(b)}$ & 0,568 & 19,880 & 0,000 & Significant \\
\hline Source: Adapted from secondary data & & &
\end{tabular}

Table 7 and Table 8 shows the value of (c), (d) is significant, and (b) significant. Path coefficient (a) is smaller than the path coefficient (b). Therefore, the nature indirect effect of mediated diversification on firm value through IOS is a partial mediation. That is, diversification can directly affect the firm value and can also through IOS. It can be stated that hypothesis as a mediating influence of IOS diversification on firm value received or (H2 Accepted).

\section{Hypothesis Testing Results (H3)}

Test results moderating variables shown in Table 9 shows that dynamics of the environment variable path coefficients $(\beta 2)$ of 0.249 , t-statistic of 4.163 and p-value of 0.000 . Positive results are significant and show that dynamics of the environment can moderate the effect of IOS on the firm value.

Table 9. Result Analysis of Variable Moderating

\begin{tabular}{llllll}
\hline & & $\begin{array}{l}\text { Original sample } \\
\text { estimate }\end{array}$ & t-statistic & p-value & Explanation \\
\hline $\mathrm{ED} \longrightarrow \mathrm{FV}^{\left(\beta^{2}\right)}$ & 0,249 & 4,163 & 0,000 & Significant \\
$\mathrm{IOS}{ }^{2} \mathrm{ED} \longrightarrow \mathrm{FV}^{\left({ }^{2}{ }_{3}\right)}$ & $-0,217$ & 0,974 & 0,333 & Nonsignificant \\
\hline
\end{tabular}

Source: Adapted from secondary data

Shown in Table 9 the test results with the IOS*ED of the interactions obtained value of path coefficient -0.217 ; t-statistic of 0.974 and p-value greater than 0.05 . Based on these results revealed that interaction between the IOS and environment dynamics does not affect firm value. Noting the significance of each path coefficient $\beta 2$ and $\beta 3$, it can be stated that ED variables are variables that are predictors of moderate/independent. Path coefficient negative interaction variable indicates that moderating variables IOS*ED is weaken the influence of IOS on firm value. Based on the analysis as described above, it can be said that hypothesis that dynamics of the environment as a moderating influence IOS to firm value is rejected (H3 rejected).

\section{Diversification Effect on Firm Value}

\section{DISCUSSION}

Analysis results the influence of diversification on firm value is significant and positive. Thus, hypothesis that more extensive secondary sector companies to diversify, hence increasing the company's value, is acceptable. These results suggest that diversification can explain the variation in the increased value of secondary sector company in Indonesia during the year 2006-2010. Palich et al. (2000) explains the diversification and performance relationship can take linear and non-linear form. This study proves that for the secondary sector in Indonesia relationship between diversification with firm values are linear. The linearity assumption is tested by relationship between the value of corporate diversification. The test result significance at p-value $0.000<0.05$, so it is said that relationship between the two variables is linear.

Linear relation model was developed from the market based view and transaction cost economies perspective. It is said that company can create value through the exploitation of market power advantages. It is a positive linear relationship between diversification and performance. Internal market based view and transaction 
cost perspective, by Montgomery (1994), is proved in this study. Reason secondary sector companies in Indonesia to diversify created by the views and approach of market-based economic transaction costs.

Market-based view approach is actually referring to the power sources that affect industry competition that comes from thinking Porter (1980), in order to formulate the company's competitive strategy related to the environment. For Porter, Environment is the industry in which the company competes. The company's ability to cope with the industrial environment is being developed (Hitt et al., 2011) referred as managing the company's resources as an integrated input. Therefore, it create a potential source of Sustainable Competitive Advantage (SCA), the company is able to outperform its competitors, the company finally can achieve superior return.

This study supports Barney (2002), which states that rationality of the company to diversify with anticompetitive motivation is to exploit the market share. Some researchers such as Amit \& Livnat (1988); Chakrabarti et al. (2002) has demonstrated significant and positive relationship between diversification on firm value. Miller (2006) concluded that relationship diversification on firm value on the 192 companies in the United States is as significant and positive. While in Indonesia, the findings are consistent Aisjah (2009) that diversification provides significant and positive effect for companies listed on the Indonesian stock market.

These results contrast with the results of Lang and Stulz (1994); Campa \& Kedia (2002) and Fukui \& Ushijima (2007). Fukui \& Ushijima research manufacturing company in Japan. The results showed that relationship of diversification and firm value is significant but negative. That is, the wider number of businesses owned by companies in Japan, the lower the firm value. This means that curve of the relationship of diversification and value of companies in Japan are non-linear (curvilinear linkage model), inverted-U-shaped model and the intermediate model. Both models happen to companies in Japan because of diversification that have been done have optimum limit. This means that company did not generate diversification benefits in accordance with the increase in the degree of diversification or even lead to an increase in some costs such as the costs of coordination, due to the increasing complexity of the company's business structure. The condition is called inverted-U model or also occurs in organization's diminishing returns (Palich et al., 2000), called the intermediate linkage model.

This study is not in line with the findings of Berger \& Ofek (1995), Li \& Wang (2003); Sulastri (2006); Kusmawati (2005); Harto (2005, 2007). Research Berger \& Ofek (1995) using a sample of 5233 companies. The results showed that diversified company have difference value loss ranged from $13 \%-15 \%$, smaller than the companies that operate in a single segment. In addition, the company's operating profit was also smaller impulse response diversified company than the focus company or operate with a single segment. Berger \& Ofek (1995) argued the conditions of lower financial performance of diversified companies than focus company cause the firm value as a whole will be lower, because the amount of excess investment performance of the company's financial results are not well diversified into the following year.

Financial performance condition of the secondary sector in Indonesia during the year 2006-2010 showed sales growth $16.94 \%$, with average sales of Rp 88 trillion per year. This suggests the secondary sector diversified companies have better sales performance. Increased sales growth was followed by an increase in operating income and net income, i.e $35 \%$ to $39 \%$ in operating profit and net income for development. Financial condition is a market share measure of secondary sector companies in Indonesia with a sizable percentage.

\section{Mediating Role of IOS as Diversification Effect on Firm Value}

The results of path analysis, to measure the IOS as a mediating of variable diversification effect on firm value, shows a significant and positive coefficient (Table 6). This means that diversification affect on firm value, either directly or indirectly, through IOS. Based on the description of the steps to determine the nature of the variables IOS (Tables 7 and 8), it was found that variable IOS affect value company (partial mediation). It means the indirect effect between diversification on firm value through IOS acquired by multiplication of product diversification effect to IOS (path coefficient 0.650 and significant) with a direct effect firm value to IOS (path coefficients 0.267 and significant). Coefficient calculation produces the indirect effect 0.174 . This means that positive direction of the indirect effect suggests that ability of diversification in enhancing firm value, which originally amounted to only 0.316 in absence of IOS, after IOS entered as a mediating variable, the diversification ability in influencing variance firm value totally increased to 0.490 .

This study was able to prove that IOS is a partial intervening variables to enhance the role MBER and MBAR and in influencing the firm value. The consequence of this finding is that companies need to pay attention to the book value of assets and the book value of equity. The book value of assets reflects the growth prospects of the company, used to see how much its assets for the company's operations. The higher the book value, the better the company growth prospects, because the company has a productive asset. The equity book value reflects the capitalization of shares on the stock market. The higher the equity book value, the better the prospects of the company in the eyes of investors and prospective investors. This condition will make funding decisions. Therefore, these two elements have a positive effect for increasing corporate value. 
The study's findings are consistent and support research Fama (1978). Direct and indirect influence of diversification on firm value through IOS is obtained from the activities of the investment itself, through the selection of projects or other measures such as the creation of new products, the replacement of more efficient engines, the development of research \& development, and mergers with other companies (Myers, 1976). Enterprise value represented by Tobin's Q is also influenced by investment opportunities and discretionary expenditure in the future (Myers, 1977).

The findings in this study support the signaling theory. IOS shown by MBAR essential enhance shareholder value. These types of investments will provide a signal about the company's growth prospects, the growth prospects for assets and market capitalization value stocks, which is reflected in the expected future equity growth. This fact is based on the assumption that maximum firm value will be acquired through the selection of investments with a positive net present value. That is, the investment expenditures have been considered and analyzed with existing methods, the selected investments with positive NPV. Fama \& French (1998) stated that investment provides a positive signal about the company's growth and capitalization growth stocks in the future, resulting an increase of firm value as a whole.

\section{Environmental Dynamics of the Moderation Effect of IOS on Firm Value}

The test results to determine interaction dynamics of IOS*environment dynamics in moderating IOS influence on firm value in manufacturing sector companies on IDX showed a nonsignificant result (Table 9). This provides the empirical results that moderating variables interaction as interaction IOS*environment dynamics does not affect the firm value. In other words, IOS would not increase the firm value if it is supported by IOS*environmental dynamics interaction. The increase in firm value will occur only if environment dynamics is not placed as moderating variables. This is evidenced by the path coefficients were significant and positive (Table 8). Therefore, the environment dynamics variable must be placed as a predictor variable/ independent variables.

Based on descriptive statistics, it show that indicator complexity has biggest factor loading of 0.808 (Table 4). Thus, the environment dynamics variables, the moderating effect of IOS on firm value, not determined by interaction of variables IOS*environmental dynamics. Complexity is actually a way to see the company's ability to overcome competition in the industry. This indicator is measured by comparing the total sales of each company against industry sales in manufacturing sector. Average complexity is $5.6 \%$. This figure shows that manufacturing sector companies in Indonesi was able to overcome the competition between companies with a relatively small percentage.

The environment dynamics in this study is a reflection of industry that can be a strength source for the company to earn above-average profits (Hitt et al., 2011). If the company is able to manage industrial environments properly, able to overcome the competition, both from new entrants and competitors are long, the company was able to increase profitability. Companies can obtain the information needed to understand the current state and predict the future. Therefore, the integration between the environment should be a concern. The source of information is necessary to know the product position in market.

The study findings suggest that moderation between IOS*environmental dynamics for IOS influence and the firm value did not have enough evidence to be supported. This finding could be interpreted that manufacturing sector company has ability to choose the right type of investment or investment with high returns that not distorted by turbulent environment. That is, although unstable environment dynamics occurs, the company was able to choose the investment type that does not change the firm value. Therefore, the interaction IOS*environmental dynamics is not able to explain the variation changes in firm value of manufacturing sector companies at Indonesia.

The findings of this study support the research conducted by Keats \& Hitt (1988). They found an insignificant relationship between environmental dimensions and operating performance. Negative path coefficient of interaction variable indicates that moderating variables IOS $*$ environmental dynamics weaken the IOS influence on firm value. This finding can be justified from a study conducted by several researchers such as Geiger \& Hoffman (1998), Zhao \& Luo (2002), Fauver et al. (2004), that company performance is affected by many factors, such as country condition, whether developed or developing countries, with different environments will produce different performance. This statement is supported by Mayer \& Whittington (2003) by comparing performance on some developed and developing countries. In two different times, it was found there are performance differences due to different environments.

This study is different from Li \& Simerly (1998) findings that relationship moderation between ownership and performance are significant and positive. The findings difference of Li \& Simerly (1998) with this study lies in measurement of dynamics environment variable. Interaction variable used is a dummy variable, whereas this study did not use a dummy. The results of this study explains that dynamic environments required to support the company performance achievement. The difference with this study may be due to differences in dynamic variables measurement. These differences can lead to differences study findings. 


\section{CONCLUSION}

This study resulted in three conclusions. First, the secondary sector of Indonesia diversified company that formed by market share were able to increase the firm value, as reflected in the value of Tobin's Q. Second, IOS acts as a partial mediation between diversification and companies value. Third, interaction between IOS* environmental dynamics does not contribute to an increase in the value of the company. The findings of this study means that manufacturing companies in Indonesia, the company's value is not determined by the interaction between IOS* environmental dynamics. This finding could be interpreted manufacturing companies have the ability to choose the right type of investment or investment with high returns that are not distorted by the turbulent environment. This means that although the dynamics of an unstable environment occurs but the company was able to choose the type of investment that no change in the value of the company. Some suggestions that may suggested are: first, still need to be developed and empirically examined the influence of diversification on the control systems at every level corporate and business unit level. This is because when companies diversify, the consequences faced was the change of organizational structure or the structure of the larger and comprehensive businesses. Therefore, it is necessary that study looked at the business structure changes because it also have an impact on policy and strategy. This condition is seen in the phenomenon of several publicly traded companies that make quite aggressive business development for a relatively short period of time. Second, growth prospects and outlook for asset capitalization of growth stocks reflect IOS variables. Therefore, it is important for companies to maintain growth with positive development from year to year. Companies that have positive growth development give positive signal to investors that company performance has good prospects.

\section{REFERENCES}

[1] Adam, Tim \& Goyal, Vidhan K. The Investment Opportunity Set and Its Proxy Variables. The Journal of Financial Research. 1 $(X X X I), 2008,41-63$

[2] Adams, Michael B. Agency Theory and the Internal Audit. Managerial Auditing Journal. 9(8), 1994, 8-12.

[3] Akhtaruddin, M \& Hossain, M. Investment Opportunity Set, Ownership Control and Voluntary Disclosures in Malaysia. JOAAG. 3(2), 2008, 25-39.

[4] Aisjah, S. Strategi Diversifikasi Korporat, Struktur Modal dan Nilai Perusahaan (Studi Pada Perusahaan yang Tercatat Di Bursa Efek Indonesia). Disertasi. Program Pascasarjana Fakultas Ekonomi Universitas Brawijaya, 2009.

[5] Amit, Raphael \& Livnat, Joshua. Diversification Strategies Business Cycles and Economic Performance. Strategic Management Journal. 99,1988, 99-110.

[6] Amihud. Y. \& Lev, B. Does Corporate Ownership Structure Affects Its Strategy Towards Diversification?. Strategic Management Journal. 20 (11), 1981

[7] Ansoff, Igor. H. Corporate Strategy. (New York: McGraw Hill, 1965).

[8] Balakrishnan, Srinivasan \& Wernerfelt, Birger. Technical Change, Competition and Vertical Integration. Strategic Management Journal. 7(4), 1986, 347-359.

[9] Barney, Jay. Gaining and Sustaining Competitive Advantage, Second Edition, (Englewood Cliffs, NJ: Prentice-Hall, 2002).

[10] Firm Resources and Sustained Competitive Advantage., Journal of Management, 17, 1991.

[11] Berger, Philip G \& Ofek, Eli. Diversification's Effect on Firm Value. Journal of Financial Economics. 37, $1995,39-65$.

[12] Bernadi, K. Jemmi. Analisis Pengaruh Cashflow dan Kebijakan Pecking Order Terhadap Leverage dan Investasi serta Dampaknya Terhadap Nilai Perusahaan (Studi Pada Perusahaan-Perusahaan Sektor Manufaktur), Disertasi, Program Pascasarjana Universitas Brawijaya, 2007.

[12] Campa, Manuel \& Kedia. Explaining the Diversification Discount. The Journal of Finance. LVII (4), 2002, 1731-1762

[13] Chakrabarti, Abhirup; Singh, Kulwant \& Mahmood, Ishtiaq. Diversification and Performance: Evidence from East Asian Firms. Strategic Management Journal. 28, 2007. 101-120.

[14] Clarkson, Kenneth and Miller, Roger Le Roy. Industrial Organization, (Mc. Graw Hill, 1983).

[15] Clarke, Jonathan, E.C. Fee, Edward. Thomas, Shawn. Corporate Diversification and Asymmetric Information: Evidence from Stock Market Trading Characteristics. Journal of Corporate Finance. 10, 2004,105-129.

[16] David, Fred R. Strategic Management: Concepts and Cases. $8^{\text {th }}$ Edition (International Edition, Prentice Hall Pearson Education, Inc. Upper Saddle River: New Jersey, 2003).

[17] Dess, Gregory G \& Beard, Donald W. Dimensions of Organizational Task Environments. Administrative Science Quarterly, 29(1), $1984,52-73$.

[18] Dickinson, Sonia \& Ramaseshan B. An Investigation of the Antecedents to Cooperative Marketing Strategy Implementation. Journal of Strategic Marketing, 12(2), 2004, 71-95

[19] Efni, Yulia, Pengaruh Keputusan Pendanaan, Keputusan Investasi, Kebijakan Dividen Terhadap Nilai Perusahaan yang Dimediasi oleh Risiko (Studi Pada Sektor Properti Dan Real Estate Di Bursa Efek Indonesia), Ringkasan Disertasi. Universitas Brawijaya Malang, 2011.

[20] Fauver, Larry, Joel F. Houston, Andy Naranjo. Cross-Country Evidence on The Value of Corporate Industrial and International Diversification. Journal of Corporate Finance, 10, 2004, 729-752.

[21] Fama, Eugene F. The Effect of a Firm's Investment and Financing Decision on the Welfare of its Security Holders. American Economic Review. 68, 1978, 272-280.

[22] Industry Costs of Equity. Journal of Financial Economics. 43, 1997, 153-193.

[23] Fama, Euegene F \& French, Kenneth R. Taxes, Financing Decisions, and Firm Value. The Journal of Finance. 53 (3), 1988, 819843.

[24] Fisher, Joseph G. Contigency Theory, Management Control Systems: Past Results and Future Directions. Behavioral Research in Accounting, 10, 1998, 47-64. 
[25] Fukui, Yoshitaka \& Ushijima, Tatsuo. Corporate Diversification, Performance and Restructuring in The Largest Japanese Manufacturers. Journal of The Japanese and International Economics. 21, 2007, 303-323.

[25] Gaver, Jennifer J \& Gaver, Kenneth M. Compensation Policy and The Investment Opportunity Set. Financial Management. 24 (1), 1995, 19-32.

[26] Geiger, Scott W \& Hoffman James J. The Impact Of The Regulatory Environment and Corporate Level Diversification on Firm Performance. Journal of Managerial Issues, 10(4), 1998, 439-453. http://www.jstor.org/stable/40604211.

[27] Ginsberg, Ari \& Ventkatraman. Contigency Perspectives of Organizational Strategy: A Critical Review of the Empirical Research. The Academy of Management Review, 10(3), 1985, 421-434.

[28] Gomes, Joao \& Livdan, Dmitry. Optimal Diversification: Reconciling Theory and Evidence. The Journal of Finance. 2 (LIX), 2004 , 507-535.

[29] Hambrick, Donald C. An Empirical Typology of Mature Industrial-Product Environments. The Academy of Management Journal, 26(2), 1983, 213-230.

[22] Harto, Puji. Kebijakan Diversifikasi Perusahaan dan Pengaruhnya Terhadap Kinerja: Studi Empiris pada Perusahaan Publik di Indonesia. SNA VIII, Solo, 15-16 September, 2005, 297-307.

[23] Hasnawati, Sri. Implikasi Keputusan Investasi, Pendanaan dan Dividen Terhadap Nilai Perusahaan Publik di Bursa Efek Jakarta. Usahawan Indonesia. No.09 TH XXXIV, 2005a, 33-41.

[24] Dampak Set Peluang Investasi Terhadap Nilai Perusahaan Publik di Bursa Efek Jakarta. Jurnal AAI. 9(2), 2005b, 117-126.

[25] Hidayat, Riskin. Keputusan Investasi dan Financial Contraints: Studi Empiris pada Bursa Efek Indonesia. Buletin Ekonomi Moneter dan Perbankan, 2010, 457-479.

[26] Hitt, Michael A. R. Duane Ireland. Robert E. Hosskison. Concepts Strategic Management Competitiveness \& Globalization 9e. (South-Western Cengage Learning: USA, 2011)

[27] Hoskisson, Robert E \& Hitt, Michael A. Antecedents and Performance Outcomes of Diversification: A Review and Critique of Theoritical Perpectives. Journal of Management. 16 (2), 1990, 461-509.

[28] Hossain, Mahmud. Ahmed, Kamran. Godfrey, Jayne M. Investment Opportunity Set and Voluntary Disclosure of Prospective Information: A Simultaneous Equation Approach. Journal of Business Finance \& Accounting. 32 (5) \& (6), $2005,871-907$.

[29] Jensen, Michael C \& Meckling, Wiliam H. Theory of the Firm: Managerial Behavior, Agency Cost and Ownership Structure. Journal of Financial Economics, 3 (4), 1976, 305-360.

[30] Jensen, Michael C. Agency Costs of Free Cash Flow, Corporate Finance, and Takeovers. American Economic Review, 76(2), 1986, 323-329.

[31] Kallapur, S \& Trombley, Mark A. The Association Between Investment Opportunity Set Proxies and Realized Growth. Journal of Business Finance \& Accounting. 26 (3 \& 4), 1999, 505-519.

[32] Keats \& Hitt. 1988. A Causal Model of Lingkages Among Environmental Dimension Macro Organizational Characteritic and Performance. Academy Management Journal. 31 (3): 570-598.

[33] Khanna, Tarun \& Palepu, Krishna. Policy Shocks, Market Intermediaries, and Corporate Strategy: The Evolution of Business Groups in Chile and India. Journal of Economics \& Management Strategy. 8(2), 1999, 271-310.

[34] Kole, S. An Investigation of The Building of Compensation. Working Paper, 1991.

[35] Kusmawati. Pengaruh Diversifikasi Usaha, Leverage, dan Ukuran Perusahaan pada Profitabitas Perusahaan Industri Terbuka di Bursa Efek Indonesia. Jurnal Riset Akuntansi Aksioma, 4 (2), 2005,100-126.

[36] Lane, Peter J. Cannelta, Albert A. Lubatkin, Michael H. Agency Problem as Antecedents to Unrelated Mergers and Diversification: Amihud and Lev Considered. Strategic Management Journal. 19(6), 1998, 555-578.

[37] Lang, Larry, H.P. \& Stulz Rene, M. Tobin's Q, Corporate Diversification and Firm Performance. Journal of Political Economy. 1994, 1248-1278.

[38] Li, Kai. Sarkar, Asani. Wang, Zhenyu. Diversification Benefits of Emerging Markets Subject to Portofolio Constraints. Journal of Empirical Finance. 10, 2003, 57-80.

[39] Li, Mingfang \& Simerly, Roy L. The Moderating Effect of Environmental Dynamism on the Ownership and Performance Relationship. Strategic Management Journal, 19(2), 1998, 169-179.

[40] Luthans, Fred \& Stewart, Todd I. A General Contigency Theory of Management. The Academy of Management Review, 2(2), 1997, 181-195.

[41] MacKay, Peter. Real Flexibility and Financial Structure: An Empirical Analysis. The Review of Financial Studies. 16 (4), 2003, 1131-1165.

[42] Matsusaka, Jhon, G. Corporate Diversification, Value Maximization, and Organizational Capabilities. Journal of Business. 74 (3), 2001,409-431.

[43] Mayer, Michael \& Whittington, Richard. Diversification in Contex: A Cross-National and Cross-Temporal Extension. Strategic Management Journal, 24(8), 2003, 773-781.

[44] Mc Arthur, Angelina W \& Nystrom, Paul C. Environmental Dynamism, Complexity and Munificence as Moderators of StrategyPerformance Relationship. Journal of Business Research, 23(4), 1991, 349-361.

[45] McDonald, Robert \& Siegel, Daniel. The Value of Waiting to Invest. The Quarterly Journal of Economics, 101(4), 1986, 707-727

[46] Mealiea, Laird W \& Lee, Dennis. An Alternatif to Macro-Micro Contingency Theories: An Integrative Model. The Academy of Management Review, 4(3), 1979, 333-345.

[47] Mintzberg, Henry. The structuring of Organizations. (Englewood Cliffs, Prentice-Hall, 1979).

[48] Miller, Douglas, J. Firm's Technological Resources and The Performance Effect of Diversification: A Longitudinal Study. Strategic Management Journal. 25, 2004, 1097-1119.

[49] Technological Diversity, Related Diversification and Firm Performance. Strategic Management Journal. 27, 2006, 601-619.

[50] Montgomery, Cynthia A. Corporate Diversification. Journal of Economic Perspectives. 8 (3), 1994, $163-178$.

[51] Myers, Stewart C. 1977. Interactions of Corporate Financing and Investment Decisions-Implications for Capital Budgeting: Reply. The Journal of Finance. 32(1), 1977, 218-220.

[52] Nayyar, Praveen R. Performance Effects of Information Asymmetry and Economies of Scope in Diversified Service Firms. Academy of Management Journal. 36 (1), 1993, 411-418.

[53] Nopratiwi, Agustina M. V. Analisis Korelasi Investment Opportunity Set Terhadap Return Saham (Pada Saat Pelaporan Keuangan Perusahaan). Tesis. Pasca Sarjana Universitas Gajah Mada: Yogyakarta, 2004.

[54] Palich, Leslie E. Cardinal, Laura B. Miller, Chet C. Curvilinearity in The Diversification-Performance Linkage: An Examination of Over Three Decades of Research. Strategic Management Journal. 21, 2000, 155-174.

[55] Pearce, John A \& Robinson, Richard B. Strategic Management: Formulation, Implementation and Control. Sixth Edition Irwin. (The McGraw-Hill Companies, Inc, 2011). 
[56] Pindyck, Robert S. A Note on Competitive Investment under Uncertainty. The American Economic Review, 83(1), 1993, 273-277

[57] Prahalad, C.K \& Hamel, Gary. The Core Competences of the Corporation. Harvard Business Review, 68(3), $1990,79-91$.

[58] Porter, Michael E. 1980. Competitive Strategy Techniques for Analyzing Industries and Competitors, (The Free Press, New York, 1980).

[59] Ray, Sougata. Environment-Strategy-Performance Linkages: A Study of Indian Firms during Economic Liberalization. Vikalpa, 29(2), 2004, 9-23.

[60] Ross, Stephen A. The Determinan of Financial Structure: The Incentive-Signalling Approach. The Bell Journal of Economics. 8 (1), 1977, 23-40.

[61] Rumelt, Richard. P. Strategy, Structure, and Economic Performance, (Harvard Business School Classic, 1974).

[62] Diversification Strategy and Profitability. Strategies Management Journal. 3 (4), 1982, 359-369.

[63] Santos, Marcelo B.D. Errunza, Vihang R. Miller, Darius P. Does Corporate International Diversification Destroy Value? Evidence from Cross-border Mergers and Acquisition. Journal of Banking \& Finance. 32, 2008, 2716-2724.

[64] Saputro, Jufanto A \& Hartono, Jugiyanto. Confirmatory Factor Analysis Gabungan Proksi Investment Opportunity Set dan Hubungannya Terhadap Realisasi Pertumbuhan. Simposium Nasional Akuntansi. Ikatan Akuntansi Indonesia, Semarang, 2002.

[65] Satoto, Sinta. H. Strategi Diversifikasi Terhadap Kinerja Perusahaan. Jurnal Keuangan dan Perbankan, 13 (2), $2009,280-287$.

[66] Sharpie, Alan. Modern Corporate Finance. Third Edition. (Macmillan Publishing Company, New York, 1991).

[67] Singh, Manohar. Wallace N. Davidson III. Jo-Ann Suchard. Corporate Diversification Strategies and Capital Structure. The Quarterly Review of Economics and Finance. 43, 2003,147-167.

[68] Smith, Jr. Clifford. W \& Watts, Ross. L. The Investment Opportunity Set and Corporate Financing, Dividend and Compensation Policies. Journal of Financial Economics. 32, 1992, 263-292.

[69] Suharli. Pengaruh Profitability dan Investment Opportunity Set Terhadap Kebijakan Dividen Tunai dengan Likuiditas Sebagai Variabel Penguat (Studi pada Perusahaan yang Terdaftar di Bursa Efek Jakarta Periode 2002-2003). Journal Akuntansi dan Keuangan. 9(1), 2007, 9-17.

[70] Sulastri. Pilihan Strategi Diversifikasi dan Implikasinya: Sebuah Pengembangan Model Teoritik. Studi Empiris pada Perusahaan Go Publik di Indonesia. Ringkasan Disertasi. Program Pasca Sarjana Universitas Dipenogoro. Semarang, 2006.

[71] Tan, Justin. Impact of Ownership Type on Environment-Strategy Linkage and Performance: Evidence from a Transitional Economy. Journal of Management Studies, 39(3), 2002, 333-354.

[72] Teece, David J, Pisano, Gary, Shuen, Amy. Dynamic Capabilities and Strategic Management. Strategic Management Journal. 18 (7), 1997, 509-533.

[73] Voght, Stephen C. Cash Flow and Capital Spending: Evidence from Capital Expenditure Announcements. Financial Management, 26(2), 1997, 44-57.

[74] Wheelen, Thomas L \& Hunger, J. David. Strategic Management and Business Policy Eleventh Edition. (Pearson International Edition, 2000)

[75] Williamson, Oliver E. The Firm, The Market and The Law by R.H. Coase. California Law Review, Inc, 77 (1), $1989,223-231$.

[76] Yoon, Pyung S \& Starks, Laura T. Signaling, Investment Opportunities, and Dividend Announcements. The Review of Financial Studies. 8 (4), 1995, 995-1018.

[77] Yuliani. Leverage, Size and Age Mediating Business Diversified to Financial Performance: Empirical Studies of Secondary Sectors in Indonesian Stock Exchange. Proceeding The $2^{\text {nd }}$ International Conference Indonesian Management Scientists Association. Pekan Baru Riau. 2-4 Desember 2011, 195-212.

[78] Zhao, Hongxin \& Luo, Yadong. Product Diversification, Ownership Structure, and Subsidiary Performance in China's Dynamic Market. Management International Review, 42(1), 2002, 27-48. http://www.jstor.org/stable/40835906. 